\title{
Application of analytical methods for determination of hardness distribution in welded joint made of S1100QL steel
}

\author{
Wiesława Piekarska ${ }^{1}$, Milan Sága ${ }^{2}$, Dorota Goszczyńska-Króliszewska ${ }^{1,}$, \\ Tomasz Domański ${ }^{1}$, Peter Kopas ${ }^{2}$ \\ ${ }^{1}$ Institute of Mechanics and Machine Design Foundations, Czestochowa University of Technology, \\ Dabrowskiego 73, 42-200 Częstochowa, Poland, EU \\ ${ }^{2}$ University of Žilina, Faculty of Mechanical Engineering, Department of Applied Mechanics, \\ Univerzitná 8215/1, 010 26, Žilina, Slovak Republic
}

\begin{abstract}
The prediction of hardness distribution in the cross section of welded join made of S1100QL steel is performed in this study on the basis of analytical methods. Analytical CCT diagram and volume fraction of each phases of S1100QL steel as a function of cooling time $t_{8 / 5}$ are determined. A numerical simulation of welding process is performed in ABAQUS. Thermal cycles and temperature field in welded joints are determined. Prediction of hardness distribution in the cross section of the joint is performed on the basis of obtained cooling times $t_{8 / 5}$. Results of numerical simulations are compared with experimentally obtained results.
\end{abstract}

Keywords: CCT diagram, analytical methods, heat affected zone, numerical modelling, welding

\section{Introduction}

Analytical models presented in paper concern to building simplified CCT diagrams, prediction the structure and evaluating mechanical properties on the basis on chemical composition of steel form the group of weldable steels [1-6]. Results of analytical methods are often used for the preliminary analysis of the properties of the material, which preceded the subsequent experimental studies and the development of mathematical models. Experimental researches are very expensive so researches are focused on the mathematical modeling of arising phenomena.

Application of analytical methods to predict the structure and hardness distribution in the cross section of S1100QL steel were presented in paper. The analyzed steel belongs to a group of high-strength steels with a yield point above $900 \mathrm{MPa}$ [7-10]. Application of highstrength steels allows to significantly reducing the weight of construction, increasing its load capacity. Consequently the demand for this kind of steels is still growing.

From the empirical relationships, the characteristic values that were used to build CCT diagram of the S1100QL steel were determined. Numerical analysis of the butt welding of

\footnotetext{
* Corresponding author: goszczynska@imipkm.pcz.pl

Reviewers: Grzegorz Domek, František Nový
} 
high-strength flat steel S1100QL was performed. In ABAQUS FEA built three-dimensional discrete model reflecting the geometry of considered model. To describe the power distribution of the welding source, a model of heat source with a Goldak's distribution was assumed. Temperature distributions, the shape and size of the melted zone of the weld joint were determined on the basis of numerical simulation. Mechanical properties such as: hardness $(\mathrm{HV})$, yield strength $\left(\mathrm{R}_{\mathrm{e}}\right)$, tensile strength $\left(\mathrm{R}_{\mathrm{m}}\right)$, elongation $(\mathrm{A})$ and contraction $(\mathrm{Z})$ were determined on the basis of experimental determined phase compositions. The hardness distribution (HV) in the cross section of the weld joint was predicted for different distances from the heat source. The results was compared with those obtained experimentally $[8,10]$.

\section{Analytical models of phase transformations}

Analytical models created on the basis of the composition of steel were used to predict the structure composition of HAZ, further to develop simplified CCT diagrams. Equations were obtained by the use of statistical analysis of results of experimental research performed for certain material groups. As a result, models developed by different authors were given, allowing the determination of characteristic quantities of austenite transformation $[1,2,4$, 6]. Chemical composition of investigated steel was presented in Table1. Symbols of chemical elements provided by all empirical formulas means percentage of a given element, e.g. $\mathrm{C} \rightarrow \% \mathrm{C}$.

Table 1. Chemical composition of S1100QL steel [atomic \%]

\begin{tabular}{|c|c|c|c|c|c|c|c|c|c|}
\hline Steel & $\mathbf{C}$ & $\mathbf{S i}$ & $\mathbf{M n}$ & $\mathbf{P}$ & $\mathbf{S}$ & $\mathbf{C r}$ & $\mathbf{M o}$ & $\mathbf{N i}$ & $\mathbf{V}$ \\
\hline S1100QL & 0.18 & 0.50 & 1.6 & 0.017 & 0.003 & 1.45 & 0.50 & 2.39 & 0.12 \\
\hline
\end{tabular}

In this paper analytical models were used to create an analytical CCT diagram with different approaches in determining the time of initiation of austenite transformation. Start and finish temperatures of each phase transformation were determined for start and finish times of phase transformations estimated in relation to the chemical composition of the analyzed steel.

Time $t_{8 / 5}$ and start times of diffusive transformations as: bainite $t_{B}$, ferrite $t_{F}$ and perlite $t_{P}$ were expressed as follows $[1,4]$ :

$$
\begin{gathered}
t_{B}=-1.8+28.3 \mathrm{C}+17.1 \mathrm{Mn}-59.6 \mathrm{Si}-20 \mathrm{Cr}+13.2 \mathrm{Ni}+0.1 \mathrm{Mo}-5.3 \mathrm{~V} \\
+47.0 \mathrm{Nb}-289.6 \mathrm{C}^{2}-3.7 \mathrm{Mn}^{2}+65.4 \mathrm{Si}^{2}+38.6 \mathrm{Cr}^{2}-7.0 \mathrm{Ni}^{2}-21.0 \mathrm{Mo}^{2} \\
-9.8 \mathrm{CMn}-19.5 \mathrm{MnSi}+232.1 \mathrm{CSi} \\
t_{F}=10^{[5.8(\mathrm{C}+\mathrm{Si} / 291+\mathrm{Mn} / 14+\mathrm{Ni} / 67+\mathrm{Cr} / 16+\mathrm{Mo} / 6+\mathrm{V} / 425)-0.83]} \\
t_{P}=10^{[5.14(\mathrm{C}+\mathrm{Si} / 17+\mathrm{Mn} / 19+\mathrm{Ni} / 25+\mathrm{Cr} / 16+\mathrm{Mo} / 4+\mathrm{V} / 3)+0.06]}
\end{gathered}
$$

where: $t_{B}, t_{F}, t_{P}$ are start times of bainite, ferrite and pearlite transformations. 
Time-dependent $\left(\mathrm{t}=\mathrm{t}_{8 / 5}\right)$ start temperatures of the formation ferrite $F_{s}(t)$, bainite $B_{s}(t)$, pearlite $P_{s}(t)$ and the finish temperature of phase transformations $T_{k}(t)$ were determined by formulas $[4,5]$, in the following form:

$$
\begin{gathered}
B_{s}(t)=T_{B 0}+\Delta T_{B} \operatorname{erf}\left[\left(\ln t-\ln t_{B 0}\right) K_{B}\right]+K_{B t} \ln t \rightarrow T_{B 0}=T_{B 0}(t)=M_{s} \\
F_{s}(t)=T_{F 0}+\Delta T_{F} \operatorname{erf}\left[\left(\ln t-\ln t_{F 0}\right) K_{F}\right]+K_{F t} \ln t \rightarrow T_{k 0}=T_{k 0}(t)=M_{s} \\
P_{s}(t)=T_{P 0}+\Delta T_{P} \operatorname{erf}\left[\left(\ln t-\ln t_{P 0}\right) K_{P}\right]+K_{P t} \ln t \rightarrow T_{F 0}=B_{s}\left(t_{F 0}\right) \\
T_{k}(t)=T_{k 0}+\Delta T_{k} \operatorname{erf}\left[\left(\ln t-\ln t_{k 0}\right) K_{k}\right]+K_{k t} \ln t \rightarrow T_{P 0}=B_{s}\left(t_{P 0}\right)
\end{gathered}
$$

where: values $\Delta T_{B}, K_{B}, \Delta T_{F}, K_{F}, \Delta T_{P}, K_{P}, \Delta T_{k}, K_{k}$ depend on the chemical composition of examined steel $[4,5]$. $[1,2]$ :

Start and finish temperatures of martensite transformation, were described respectively

$$
\begin{gathered}
M_{s}=530-415 C+90 C^{2}-35 M n-30 C r-20 N i-15 \mathrm{~W}-10 \mathrm{Mo} \\
M_{f}=381.76-252.44 C-111.12 \mathrm{Mn}+54.538 \mathrm{Si}+114.17 \mathrm{Cr} \\
-23.779 \mathrm{Ni}-57.381 \mathrm{Mo}+215.7 \mathrm{~V}+945.4 \mathrm{Nb}+1821.7 \mathrm{Ti}-1746.5 \mathrm{~B}
\end{gathered}
$$

The CCT diagrams of S1100QL steel by using the formulas (1-9) were given in Figure 1. For comparison the experimental CCT diagram obtained by [8] was presented in Figure 1.

Depending on cooling rates the analytical model for determining phase composition is very useful in phase transformation analysis. The volume fractions of particular phases, such as: ferrite-pearlite $\left(\eta_{F P}\right)$, bainite $\left(\eta_{B}\right)$ and martensite $\left(\eta_{M}\right)$, as a function of time $\mathrm{t}_{8 / 5}$ were described as follows $[1,2]$ :

$$
\begin{gathered}
\eta_{M}=0.5\left[1-\operatorname{erf} \frac{\left((\ln t)-\ln \Delta t_{F P}\right)}{\ln S_{F P}}\right. \\
\eta_{F P}=0.5\left[1-\operatorname{erf} \frac{\left((\ln t)-\ln \Delta t_{M}\right)}{\ln S_{M}}\right. \\
\eta_{B}=1-\eta_{M}-\eta_{F P}
\end{gathered}
$$

where: $\ln \Delta t_{F P}, \ln \Delta t_{M}, \ln \mathrm{S}_{F P}, \ln \mathrm{S}_{M}$ depend on the chemical composition of examined steel $[1,2]$. 


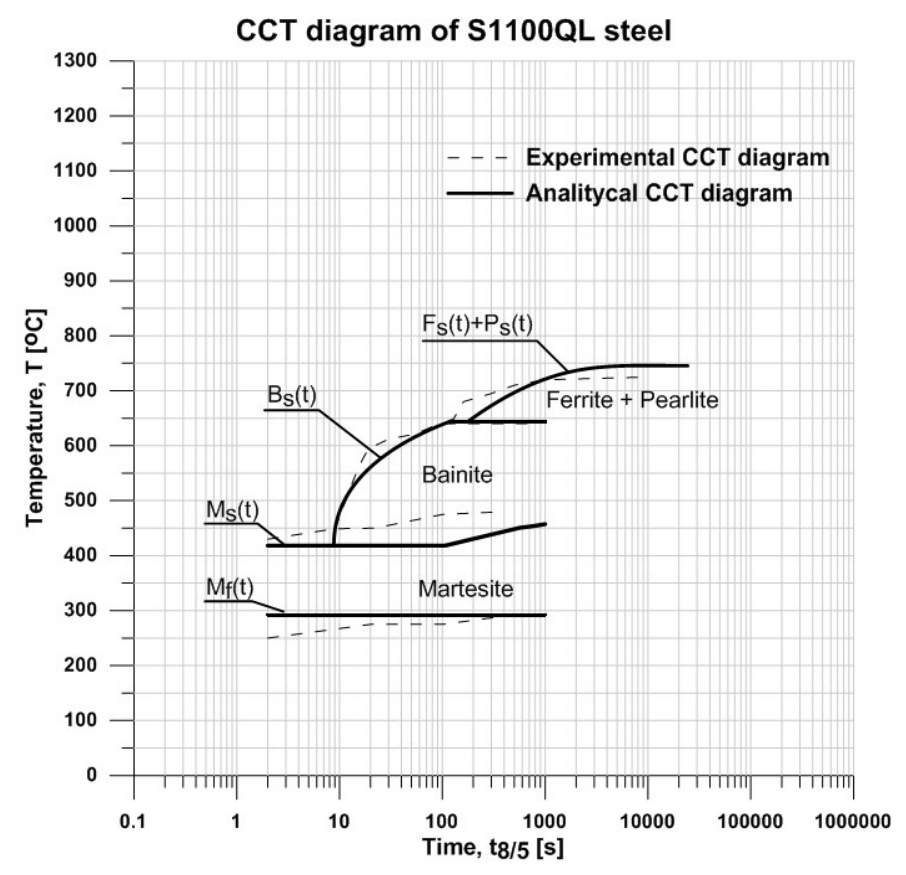

Fig. 1. Analytical and experimental [8] CCT diagram of S1100QL steel

\section{Analytical methods for predicting a hardness distribution}

Mechanical properties HAZ of the weld joint can be determined from the structural composition and mechanical properties of each of the structures. If the phase composition in the heat affected zone is known, more specifically contribution of each structure (ferritepearlite, martensite and bainite) and properties of structural components $W_{i}$, there is a possibility to approximately predict properties of the entire zone [3].

$$
W=\sum_{i=M, B, F, P} W_{i} \eta_{i}
$$

where: $W$ can be mean hardness, yield strength, tensile strength, impact strength, elongation and contraction.

In the literature $[1,2,5,6]$ are administered many dependencies, which can be determine the mechanical properties such as $R_{e}, R_{m}, A_{5}, Z, K C U$ and $H V$. Property of each phases: ferrite-pearlite, martensite and bainite were defined on the based on chemical composition. Whereas contributions each phases were defined based on the experiment or through used numerical simulations.

Hardness, mapping the structural heterogeneity of the HAZ, is one of the basic volume which characterized the welded joint. Hardness of HAZ is a function of phase composition and hardness for each structure of phases. $\mathrm{HV}_{\mathrm{i}}$ ( $i$ means each phases such as: ferritepearlite, martensite and bainite). Hardness $\mathrm{HV}_{\mathrm{i}}$ of individual structural components was defined by [10] as a function of chemical composition and velocity $v_{8 / 5}$ $\left(v_{8 / 5}=(800-500) / t_{8 / 5}\right)$ : 


$$
\begin{aligned}
& H V_{F P}=42+223 C+53 S i+30 M n+12.6 N i+7 C r+19 M o+ \\
& +(10-19 S i+4 N i+8 C r+130 V) \log v_{8 / 5} \\
& H V_{M}=127+959 C+27 S i+11 M n+8 N i+16 C r+21 \log v_{8 / 5} \\
& H V_{B}=-323+185 C+330 S i+153 M n+65 N i+144 C+ \\
& +191 M o+(89+53 C-55 S i-22 M n-10 N i-20 C r-33 M o) \log v_{8 / 5}
\end{aligned}
$$

Authors of papers $[8,10]$ performed experimental research of base material of S1100QL steel [8]. Structure of base material of S1100QL steel consisted in fine-grained martensite (grain diameter about 1-8 mm), bainite and ferrite (Fig. 2).

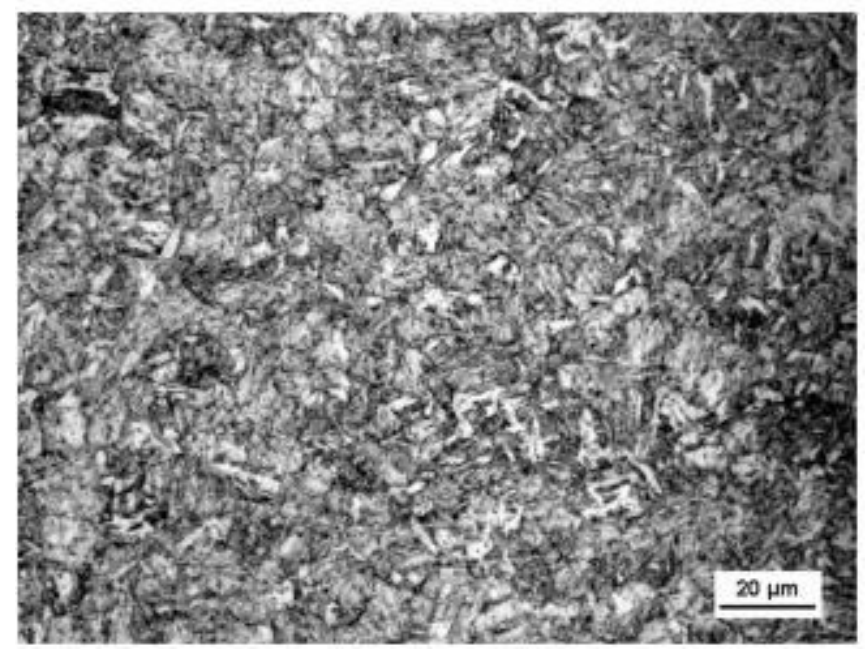

Fig. 2. Microscopic image of the base material of S1100QL steel [8]

Mechanical properties in base material were determined analytically on the basis of relationships in papers $[1,2,5,6]$. Structures of base material were performed experimentally. Analytical and experimental results were presented in table 2 [10].

Table 2. Mechanical properties of base material of S1100QL steel

\begin{tabular}{|c|c|c|c|c|c|}
\hline Results & $\mathbf{H V}$ & $\mathbf{R}_{\mathbf{e}}[\mathbf{M P a}]$ & $\mathbf{R}_{\mathbf{m}}[\mathbf{M P a}]$ & $\mathbf{A}[\mathbf{\%}]$ & $\mathbf{Z}[\mathbf{\%}]$ \\
\hline Experimental [10] & 320 & 1120 & 1430 & 12.5 & 58 \\
\hline Analytical & 318 & 1139 & 1377 & 15.05 & 48.02 \\
\hline
\end{tabular}

\section{Field temperature, phase transformations, kinetic of transformations}

The exemplary of prediction of hardness distribution in the cross section of flat butt welded by electric arc made of S100QL steel was performed in this study. Field temperature of welded joint was determined on the basis of finite element methods $[11,12,13]$ in ABAQUS FEA software. The analysis of thermal phenomena is made on the basis of the solution of energy conservation equation together with Fourier law [14]. The temperature field expressed in the criterion of weighted residuals method was described by the following equation: 


$$
\int_{V} \rho \frac{\partial U}{\partial t} \delta T d V+\int_{V} \frac{\partial \delta T}{\partial x_{\alpha}} \cdot\left(\lambda \frac{\partial T}{\partial x_{\alpha}}\right) d V=\int_{V} \delta T q_{V} d V+\int_{S} \delta T q_{S} d S
$$

where: $\lambda$ thermal conductivity $[\mathrm{W} / \mathrm{mK}], \mathrm{U}=\mathrm{U}(\mathrm{T})$ is internal energy, $q_{v}$ is the capacity of source $\left[\mathrm{W} / \mathrm{m}^{3}\right], T=T\left(x_{\omega}, t\right)$ is temperature $[\mathrm{K}], q_{s}$ is density of heat $\left[\mathrm{W} / \mathrm{m}^{2}\right]$, and $\delta T$ is a partial differential of $T$.

Equation (15) is completed by the initial condition and, boundary conditions of Dirichlet, Neumann and Newton type with the heat loss due to convection and radiation [15-17].

A movable welding source is implemented in Abaqus/FEA using additional numerical DFLUX subroutine [2, 14]. For the calculation of the temperature field assumed power of the heat source: $Q=2200 \mathrm{~W}$ and welding speed: $v=10 \mathrm{~mm} / \mathrm{s}$. Mathematical model of Goldak's volumetric heat source power distribution was used in the analysis [18]:

$$
\begin{gathered}
q_{f}(x, y, z)=\frac{6 \sqrt{3} f_{f} Q}{a b c_{f} \pi \sqrt{\pi}} \exp \left(-3 \frac{x^{2}}{a^{2}}\right) \exp \left(-3 \frac{y^{2}}{c_{f}{ }^{2}}\right) \exp \left(-3 \frac{z^{2}}{b^{2}}\right) \\
q_{r}(x, y, z)=\frac{6 \sqrt{3} f_{f} Q}{a b c_{r} \pi \sqrt{\pi}} \exp \left(-3 \frac{x^{2}}{a^{2}}\right) \exp \left(-3 \frac{y^{2}}{c_{r}{ }^{2}}\right) \exp \left(-3 \frac{z^{2}}{b^{2}}\right) \\
q(x, y, z)=q_{f}(x, y, z)+q_{r}(x, y, z)
\end{gathered}
$$

where: $a, b, c_{r}$ and $c_{f}$ are dimensions of semi-ellipsoid axes, $f_{f}$ and $f_{r}$ are values representing energy distribution in the frond and the back of the heat source, $\left(f_{r}+f_{f}=2\right)$.

Numerical calculations of the temperature field were performed as a $3 \mathrm{D}$ task. Prediction of hardness distribution was performed on the basis of determined temperature distribution. Figure 3 presented results of numerical simulation in ABAQUS FEA software. Areas of weld, heat affected zone, base material, and direction of the heat source were marked.

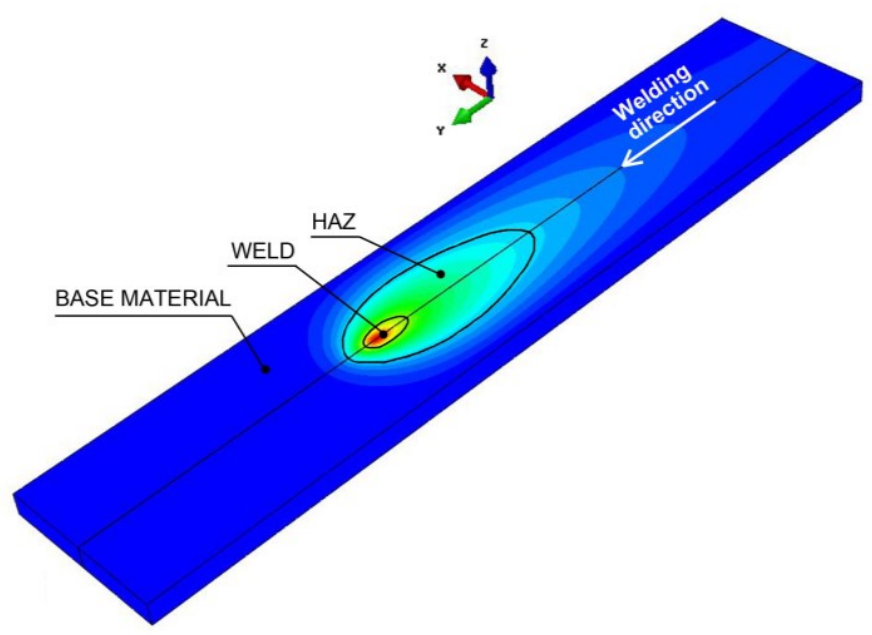

Fig. 3. Numerical model of welded flat of S1100QL steel 


\section{Exemplary of calculations}

Analysis of hardness distribution was performed for 42 selected points of the welded joint in the cross section (Fig. 4). Prediction of hardness in weld and HAZ of welded joint were performed on the basis of equations 13 and 14 and analytically obtained phase volume fraction on the function of time $t_{8 / 5}$.

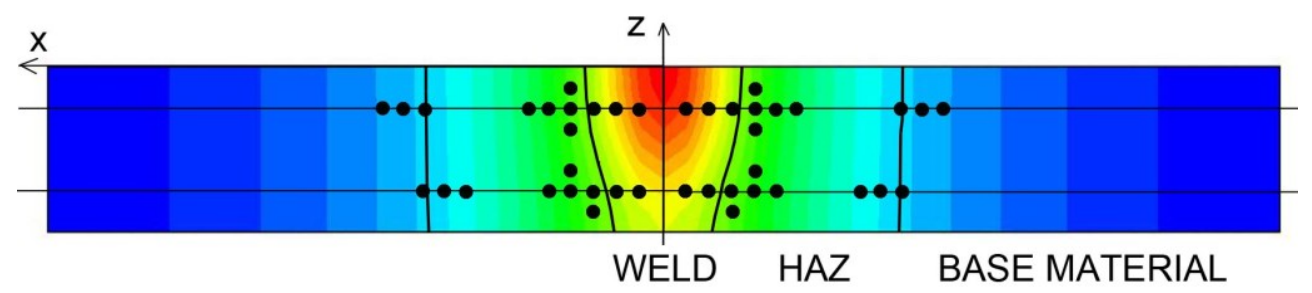

Fig. 4. Cross section of welded joints and hardness measurement points

Thermal cycles for selected point of cross section of welded joint were performed in order to determined cooling times $t_{8 / 5}$ (Fig. 5). Prediction of hardness distributions of cross section of welded joints was determined on the basis of analitycally obtained phase volume fraction and numerically obtained cooling times $t_{8 / 5}$.

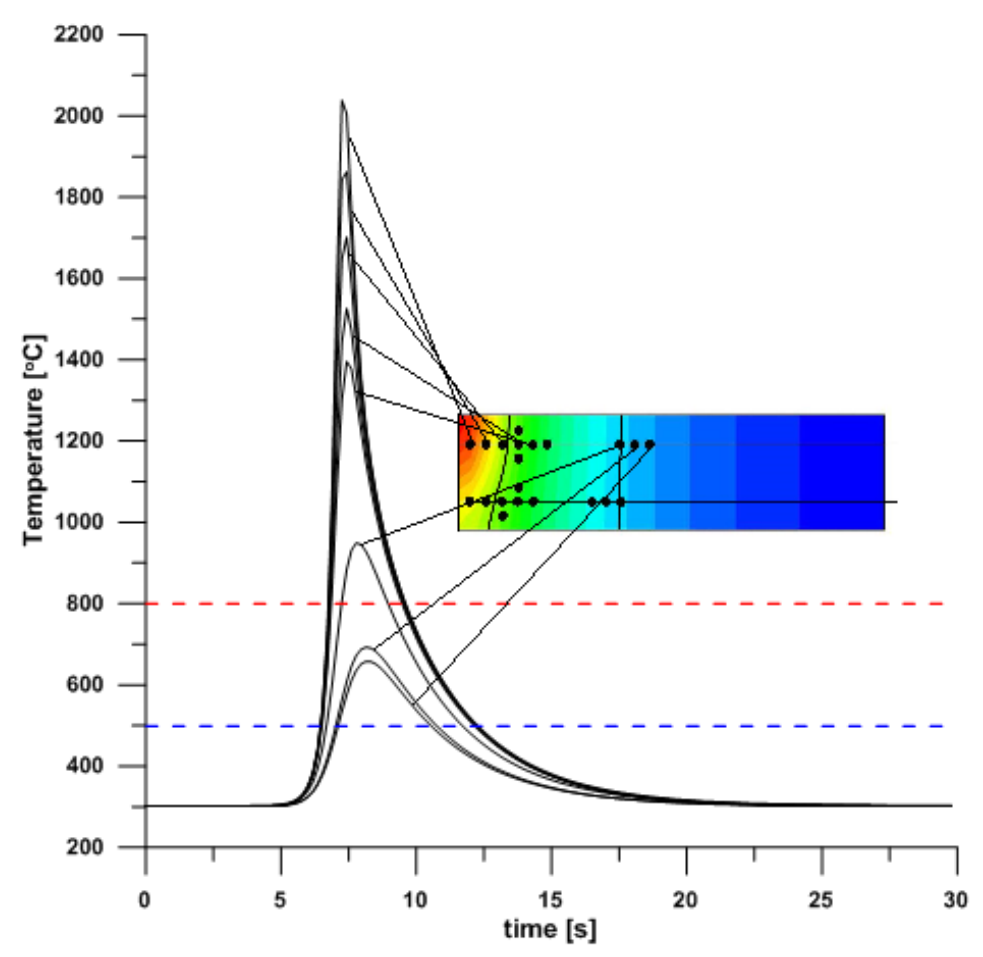

Fig. 5. Thermal cycles of measurement points (face)

Figure 6 presents results obtained analitycally of prediction of hardness distribution of selected points in cross section of welded jolint. The results of experimental research presented by the authors [8] were compared in Figure 6. 

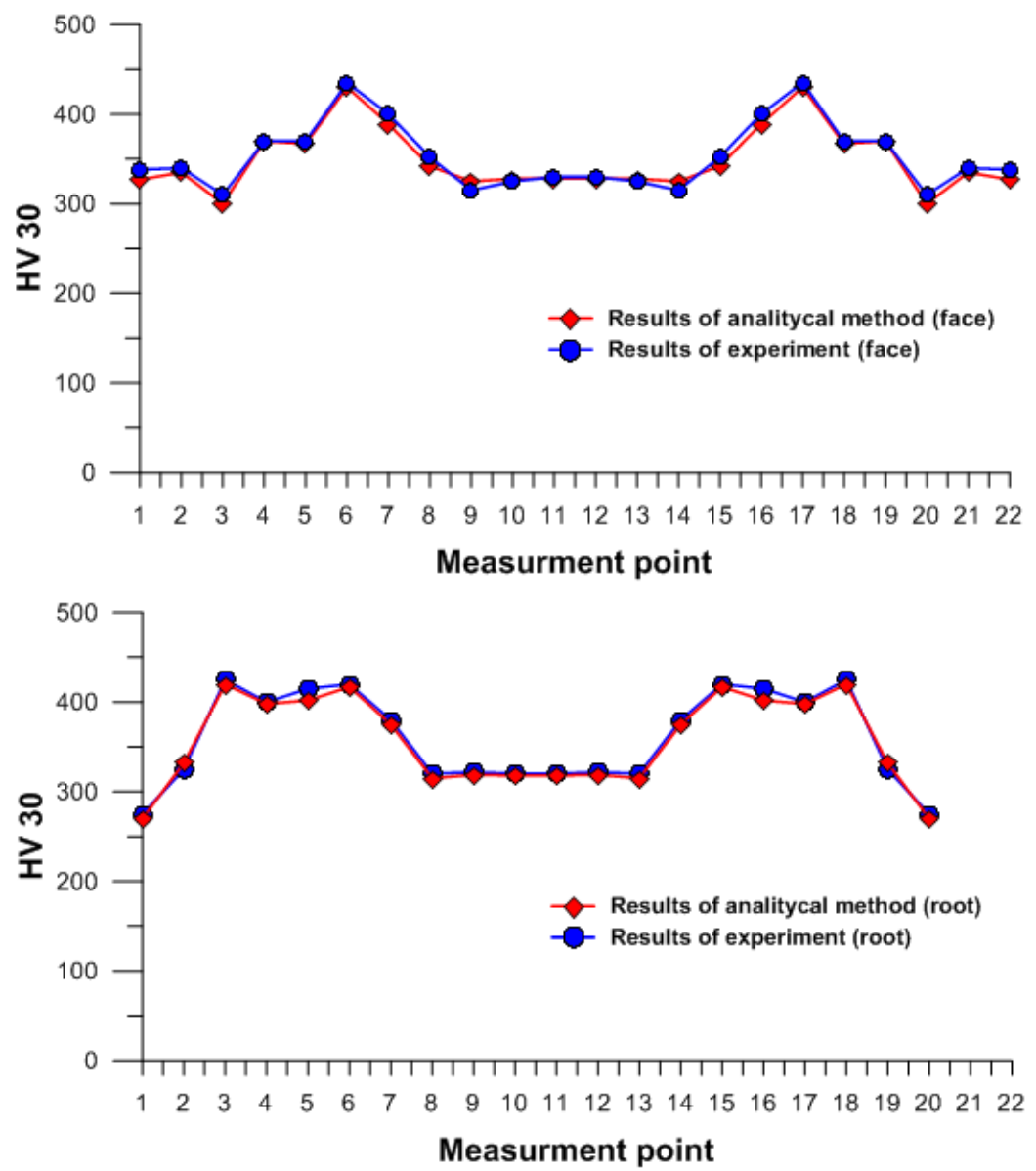

Fig. 6. Hardness distribution in the cross section of welded joint

\section{Conclusions}

The usefulness of analytical methods to predict the structure and mechanical properties in welded joint was presented in this work. Analytical CCT diagram of S1100QL steel was verified by experiment. Prediction of mechanical properties of welded joints was performed on the basis of experimentally obtained phase volume fraction. Result of hardness distribution in cross section of welding joint of S100QL steel on the basis of analytical methods were presented in paper. Results of analytical methods were compared with experimental results. Comparison of analytical and experimental results allowed to conclude that analytical methods can be applied for the preliminary analysis of material properties intended for different welded constructions. They can also be used as input data in numerical analysis of stresses and deformations in welded elements, substituting expensive experimental research in this field. 


\section{References}

1. J. Mikuła, Analityczne metody oceny spawalności stali. Zeszyty naukowe Mechanika 85, Politechnika Krakowska, Kraków (2001)

2. W. Piekarska, Analiza numeryczna zjawisk termomechanicznych procesu spawania laserowego. Pole temperatury, przemiany fazowe i naprężenia. Seria Monografie 135, Wydawnictwo Politechniki Częstochowskiej, Częstochowa (2007)

3. H. Shen, Y. Shi, Z. Yao, J. Hu, An analytical model for estimating deformation in laser forming. Computational Materials Science 37, 593-598, (2006)

4. P. Seyffart, O. G. Kasatkin, Rascentnye modeli dla ocenki mechaniceskich svojstv metalla ZTV pri svarke nizkoegirovannych stalej. Proc. Int. Conference mechanical Modelling and Information Technologies in Welding and Related Processes, Welding Inst. of NAS of Ukraine, Kiev 103-106 (2002)

5. P. Seyffart, O. G. Kasatkin, Interpolâcionnye modeli dlâ ocenki fazovogo sostava zony termičeskogo vliâniâ pri dugovoj svarke nizkolegirovannyh stalej. Avtomat. Svarka 1, 7-11 (1984)

6. P. Seyffart, O. G. Kasatkin, Mathematisch-statistische Beschreibung der Austenitumwandlung in der Wärmeeinflußzone. Schweißtechnik 29, 117-119 (1979)

7. A. Klimpel, K. Luksa, Ł. Warcaba, T. Szorek, A. Kiełbasiński, Zrobotyznowane spawanie GMA złaczy blach ze stali S690 i S960. Archiwum Technologii Maszyn i Automatyzacji 3, 30, 59-68 (2010)

8. J. Nowacki, A. Sajek, P. Matkowski, The influence of welding heat input on the microstructure of joints of S1100QL steel in one-pass welding. Archives of Civil and Mechanical Engineering 16, 777-783 (2016)

9. T. Ślęzak, L. Sniezek, Fatigue Properties and Cracking of High Strength Steel S1100QL Welded Joints. Key Engineering Materials 598, 237-242 (2014)

10. I. Samardžić, A. Corić, M. Dunđer, Weldability investigation of fine-grained $1100 Q L$ steel. Metalurgija 3, 55, 453-456 (2016)

11. T. Domanski, A. Sapietova, M. Saga, Application of Abaqus software for the modeling of surface progressive hardening. Procedia Engineering 177, 64-69 (2017)

12. M. Sapieta, V. Dekýš, A. Sapietová, Thermal-stress analysis of beam loaded by 3 point bending. Procedia Engineering 136, 216-219 (2016)

13. A. Sapietová, V. Dekýš, M. Dudinský, Utilizing of sensitivity analysis in preparation of optimizing procedure. Scientific Journal of Silesian University Of Technology, Series Transport 76, 113-118 (2012)

14. SIMULIA Dassault System. Abaqus theory manual, Version 6.7 (2007)

15. M. Kubiak, W. Piekarska, Z. Saternus, T. Domański, S. Stano, Simulations And Experimental Research On Laser Butt-Welded T-Joints. METAL 2014: 23RD International Conference On Metallurgy And Materials, 726-731 (2014)

16. R. Dyja, E. Gawronska, N. Sczygiol, The effect of mechanical interactions between the casting and the mold on the conditions of heat dissipation: a numerical model. Archiv Metall Mater. 60 (3), 1901-1909 (2015)

17. L. Sowa, A. Bokota: Numerical simulation of the molten steel flow in the tundish of CSC machine. Archives of Metallurgy and Materials 57 (4), 1163-1169 (2012)

18. J. A. Goldak, Computational Welding Mechanics. (Springer, NY, 2005) 